\title{
Review of Drying Methods for Spent Nuclear Fuel
}

by

W. S. Large

Westinghouse Savannah River Company

Savannah River Site

Aiken, South Carolina 29808

R. L. Sindelar

DOE Contract No. DE-AC09-96SR18500

This paper was prepared in connection with work done under the above contract number with the U.S. Department of Energy. By acceptance of this paper, the publisher and/or recipient acknowledges the U.S.

Government's right to retain a nonexclusive, royalty-free license in and to any copyright covering this paper, along with the right to reproduce and to authorize others to reproduce all or part of the copyrighted paper. 


\title{
REVIEW OF DRYING METHODS FOR SPENT NUCLEAR FUEL (U)
}

\author{
W. S. Large and R. L. Sindelar \\ Spent Fuel Storage Division \\ Spent Fuel Engineering \\ $\&$ \\ Savannah River Technology Center \\ Strategic Materials Technology Department \\ Materials Technology Section
}

Publication Date: April 1997

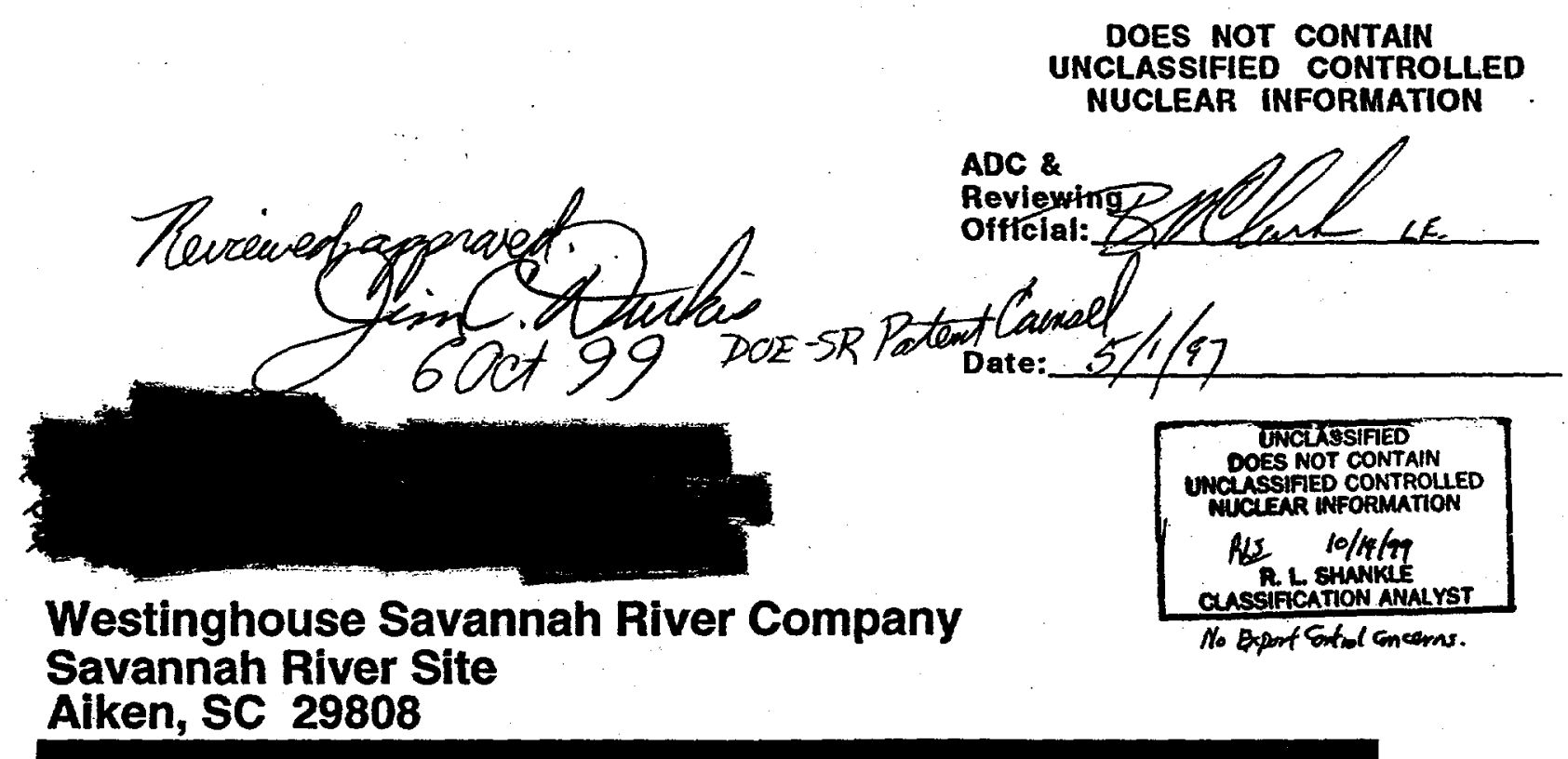

This document was prepared in connection with work done under Contract No. DE-AC09-96SR18500 with the U. S. Department of Energy 


\section{DISCLAIMER}

This report was prepared as an account of work sponsored by an agency of the United States Government. Neither the United States Government nor any agency thereof, nor any of their employees, makes any warranty, express or implied, or assumes any legal liability or responsibility for the accuracy, completeness, or usefulness of any information, apparatus, product, or process disclosed, or represents that its use would not infringe privately owned rights. Reference herein to any specific commercial product, process, or service by trade name, trademark, manufacturer, or otherwise does not necessarily constitute or imply its endorsement, recommendation, or favoring by the United States Government or any agency thereof. The views and opinions of authors expressed herein do not necessarily state or reflect those of the United States Government or any agency thereof.

This report has been reproduced directly from the best available copy.

Available to DOE and DOE contractors from the Office of Scientific and Technical Information, P.O. Box 62, Oak Ridge, TN 37831; prices available from (615) 576-8401.

Available to the public from the National Technical Information Service, U.S. Department of Commerce, 5285 Port Royal Road, Springfield, VA 22161.

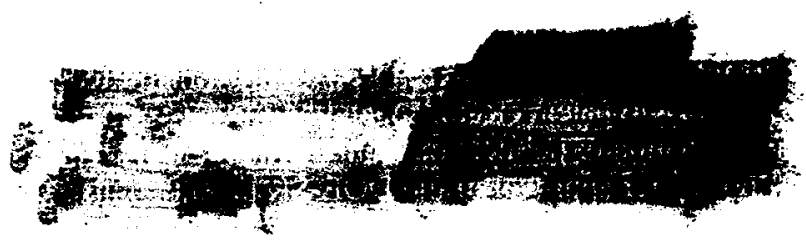




\section{DISCLAIMER}

Portions of this document may be illegible in electronic image products. Images are produced from the best available original document. 
DOCUMENT: WSRC-TR-97-0075

TITLE:

\section{REVIEW OF DRYING METHODS FOR SPENT NUCLEAR FUEL (U)}

TASK:

SRT-MTS-96-2047, Rev. 1, PLAN FOR DEVELOPMENT OF TECHNOLOGIES FOR DIRECT DISPOSAL OF ALUMINUM SPENT NUCLEAR FUEL

\section{APPROVALS}

W.\&. Large

W. S. Large, Author

Spent Fuel Storage Engineering SPENT FUEL STORAGE DIVISION

R. L. Sindelar, Author

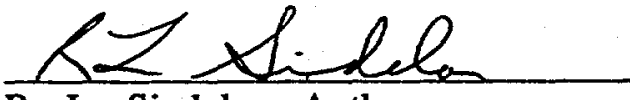

Materials Applications \& Corrosion Technology Group MATERIALS TECHNOLOGY SECTION

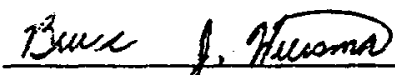

B. J. Wietsma; Reviewer

Materials Applications \& Corrosion Technology Group MATERIALS TECHNOLOGY SECTION

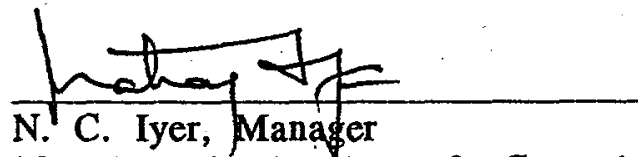

Materials Applications \& Corrosion Technology Group MATERIALS TECHNOLOGY SECTION

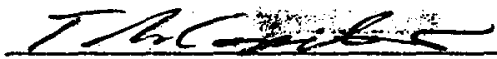

T. L. Capeletti, Manager MATERIALS TECHNOLOGY SECTION

$$
\text { wz twiy }
$$

W. F. Swift, Manager

Spent Fuel Engineering

SPENT FUEL STORAGE DIVISION

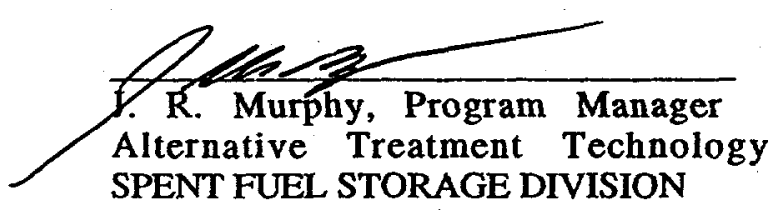

Date $3 / 20 / 97$

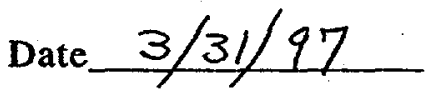

Date 4/30/97

Date $4 / 30 / 97$

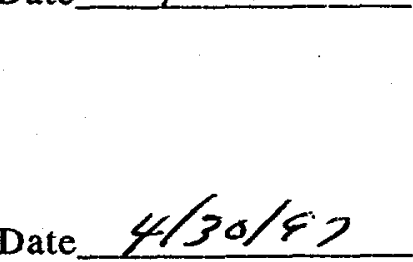

Date

Date $5 / 1 / 97$

Date $4 / 29 / 97$ 
1.0 SUMMARY $\quad \therefore 3$

2.0 INTRODUCTION 4

2.1 Background 4

2.2 SNF Disposal Issues Related to Conditioning 4

3.0 SNF DRYING, CONDITIONING, \& STORAGE PROGRAMS

3.1 Hanford Uranium Metal SNF 5

3.2 INEEL "At Risk" SNF 7

3.3. INEEL Three Mile Island SNF 9

3.4 Proposed INEEL Dry Storage Facility 9

$\begin{array}{lll}4.0 & \text { PRIOR SRS DRYING PROGRAMS } & 10\end{array}$

4.1 Unirradiated SNF 10

4.2 Reactor Heat Exchangers 11

5.0 STORAGE CRITERIA FOR SRS ALUMINUM SNF 12

5.1 Aluminum SNF Corrosion 12

$\begin{array}{ll}5.2 \text { Hydrogen and Hydride Buildup } & 13\end{array}$

$\begin{array}{lll}6.0 & \text { ALUMINUM SNF DRYING } & 14\end{array}$

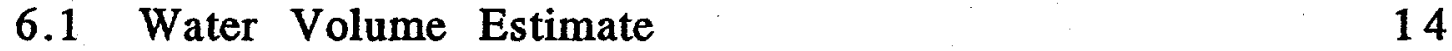

6.2 Drying Test Program 14

$\begin{array}{llr}7.0 & \text { REFERENCES } & 15\end{array}$

8.0 APPENDICES $\quad$ A 1 


\subsection{SUMMARY}

A practical method for drying aluminum-based spent nuclear fuel (SNF) at the Savannah River Site has been proposed. The drying methodology is based on achieving a level of dryness that allows acceptable, safe storage of SNF. Drying and stabilization techniques to prepare SNF for dry storage at other DOE sites have also been reviewed. Table 1 summarizes methods under development at the Hanford site and at the Idaho National Engineering and Environmental Laboratory (INEEL).

Aluminum SNF with minimal corrosion may be effectively prepared for extended dry storage via vacuum drying at slightly elevated temperatures $\left(\sim 120^{\circ} \mathrm{F}\right)$. Achieving a vacuum below $\sim 87$ torr within a heated canister will vaporize free liquid water. Achieving a vacuum below the triple point of water (4.6 torr) is within the capability of standard vacuum pump systems and will ensure dryness. High temperature drying to release hydrated water from aluminum oxide on the SNF cladding is not required because the quantity of water is insufficient to cause excessive additional corrosion. Negligible amounts of uranium hydride are expected on aluminum SNF retrieved from water storage, and further conditioning or conversion of corrosion products to eliminate an ignition hazard is not needed.

A drying demonstration with mock material test reactor (MTR) assemblies should be initiated to quantify drying system performance. A follow-up vacuum drying demonstration should be integrated into the proposed test program for dry storage and surveillance of sample MTR assemblies. Irradiated MTR assemblies will be loaded into instrumented test canisters in $L$ Area and monitored for an extended period to demonstrate the validity of proposed storage criteria [Ref. 1, subtask 1.3]. The proposed drying demonstrations will provide operational experience and aid optimization of drying equipment and methodology. Existing surplus vacuum drying equipment can be utilized to minimize costs.

The feasibility of evaporating free water from MTR SNF via simple low humidity hot air drying is still being evaluated and may be included in the demonstrations. 


\subsection{INTRODUCTION}

\subsection{Background}

SRTC is developing technology for direct disposal of aluminum spent nuclear fuel (SNF). The development program includes analyses and tests to support design and safe operation of a facility for "road ready" dry storage of SNF-filled canisters. The current technology development plan includes review of available SNF drying methods and recommendation of a drying method for aluminum SNF [Ref. 1, subtask 1.2].

\subsection{SNF Disposal Issues Related to Conditioning}

Conditioning SNF for ultimate disposal within a geologic repository is a primary technology development objective for aluminum. SNF. Conditioning is the process whereby SNF is dried or stabilized against undesirable degradation. A one-time conditioning process for interim dry storage of SNF at SRS and subsequent disposal within the repository is desired. 10 CFR Part $60.135(b)(2)$ prohibits free liquids inside repository waste packages in amounts that could compromise waste package containment or cause spread of radioactive contamination. Rapid corrosion of unconditioned SNF and/or packaging materials after placement could invalidate ongoing repository performance assessments.

Formation of uranium hydride is a storage and disposal concern for uranium metal fuels. 10 CFR $60.135(\mathrm{~b})(1)$ prohibits pyrophoric materials inside repository waste packages in amounts that could compromise waste isolation or performance objectives. Uranium hydride is potentially pyrophoric and can form beneath breached cladding on uranium metal SNF. Hydride formation initiates when water vapor adsorbs to uranium oxide surfaces [2]. The water dissociates into hydroxyl and hydrogen via radiolysis. The hydroxyl diffuses to the metal surface and reacts with uranium to form additional oxide and liberate additional hydrogen. Hydride forms when sufficient hydrogen accumulates at the surface of the uranium metal beneath the oxide. Elemental uranium expands greatly and breaks up into fine particulates upon hydriding or oxidizing. Uranium hydride reacts with water to form uranium oxide. Uranium hydride remains on uranium metal in water storage only. if occluded from water. 
Uranium hydride also reacts rapidly with oxygen when exposed to air; the kinetics of the reaction depend on the air temperature and hydride particle size. The oxidation process produces uranium oxide and water and generates significant heat. High temperatures accompanying runaway oxidation can lead to ignition of the uranium base metal.

\subsection{SNF DRYING, CONDITIONING, AND STORAGE PROGRAMS}

Multiple SNF drying and stabilization methods are under development at the Hanford and INEEL sites (Table 1). These methods utilize a combination of vacuum drying and high temperature passivation to remove water and reduce the likelihood of pyrophoric corrosion product formation during extended dry storage.

\subsection{Hanford Uranium Metal SNF}

A major program is currently underway to transfer $\sim 103,000$ SNF assemblies ( 2100 metric tons uranium) from the Hanford $\mathrm{K}$ East and $\mathrm{K}$ West storage basins near the Columbia River into dry storage [3]. The SNF is primarily low enrichment uranium metal production reactor assemblies clad with Zircalloy. The assemblies are 1.4 to 2.4 inches in diameter and up to 26 inches long. Cladding damage has led to swelling from oxide formation and an accompanying volume increase. This swelling caused additional splitting of the cladding and extensive uranium corrosion during extended storage in the Basins. SNF removal from the K-Basins is currently scheduled to begin in late 1997 or early 1998 utilizing drying and stabilization processes outlined below.

SNF assemblies will first be cleaned inside a "tumbling washer" and rinsed with a high pressure spray to remove exterior crud and corrosion. Cleaned SNF will be loaded into baskets underwater and placed into multi-canister overpacks (MCO's) for subsequent drying and storage. The MCO's are 24-inch $O D$ by 166-inch-long stainless steel canisters designed for up to 75 years storage. About $400 \mathrm{MCO}$ 's will be utilized to store the K Basin SNF. Each MCO holds 270 to 288 assemblies with a maximum gross weight of $\sim 20,360$ pounds flooded. The top of the MCO will be raised to the surface of the water after loading and closed with a screwed shield plug. The MCO will be placed inside a shielded cask upon removal from the Basin and transported to a new cold vacuum drying facility adjacent to the K Basins. 
The MCO holds 150-180 gallons of water after fully loading with assemblies [4]. The MCO will be purged with pressurized gas via ports in the shield plug to remove the bulk of free water. An estimated 2-4 liters (0.5-1 gal) of residual water within the MCO will be removed via vacuum drying. A 4 horsepower four-stage Balzers/Pfeiffer Unidry 050 vacuum pump has been purchased for this application. Pump capacity is $34 \mathrm{cfm}$ with a base pressure of 0.04 torr $(0.0007 \mathrm{psia})$. The pump chamber does not require oil lubrication and is water-vapor tolerant. Each MCO will be initially evacuated to a pressure of $\sim 10$ torr ( 0.19 psia) to promote vaporization of the residual water. A condenser and HEPA filter upstream of the pump inlet will remove particulates and vapor from the air stream. The vacuum pump will discharge through a second HEPA filter into a ventilation system exhaust stack. The vacuum drying system has been designed to remove a maximum of 15 liters $(4 \mathrm{gal})$ of water per MCO.

Warm water will be circulated through the 1/4-inch annulus between the MCO and cask liner to prevent freezing of water within the MCO during vacuum drying. Water will enter underneath the MCO base, flow upward through the annulus, and exit at the top. Average water temperature will be maintained at $50^{\circ} \mathrm{C}\left(120^{\circ} \mathrm{F}\right)$.

The acceptance criteria for SNF dryness is a final pressure of 0.5 torr ( 0.01 psia) inside the MCO. The vacuum pump will be isolated after achieving 0.5 torr, and MCO internal pressure will be monitored to ensure all water has been removed. MCO pressure will rise if moisture, such as water trapped beneath SNF cladding discontinuities, is subsequently released. Pressure must remain below 3 torr ( 0.06 psia) after one hour for final MCO acceptance. The MCO will be leak checked and vacuum dried again if the pressure rises above 3 torr. For comparison, a pressure of 3 torr equates to -2 grams of water vapor or $\sim 11 \%$ relative humidity inside a loaded MCO with the dimensions cited above (Appendix A). 
MCO's will be transported to the Canister Storage Building after drying to await further conditioning and long term storage. A new $300^{\circ} \mathrm{C}$ vacuum conditioning system is currently being designed to ensure long-term SNF stability by passivating the uranium metal and removing chemically bound water of hydration in the corrosion products. Removing the water of hydration will eliminate the potential for gradual moisture release and hydrogen formation inside the canister during long term storage.

Hydrogen could react with uranium metal as described earlier to form additional potentially pyrophoric uranium hydrides. The initial amount of hydrated oxide and potential amount of uranium hydride produced via this process was not reported. The conditioning process includes a step to stabilize the SNF by converting existing uranium hydrides to oxides. The MCO will be purged with a small quantity of oxygen in an inert carrier gas to achieve slow, controlled oxidation and formation of an oxide film.

\subsection{INEEL "At Risk" SNF}

Three programs are under development at INEEL to provide improved SNF storage. The first program will transfer $\sim 315$ assemblies or handling units from the Chemical Processing Plant (CPP) 603 Basin into dry storage [5]. The seven fuel types to be transferred are at highest risk from continued corrosion within the storage basin and include $\mathrm{UAl}, \mathrm{UZrH}, \mathrm{UO}_{2}, \mathrm{U}_{3} \mathrm{O}_{8}$ alloys and uranium metal. SNF geometries include 12-inch to 50-inch-long plates, 28-inch to 37-inch long rods, and a 220 kilogram uranium flux filter. Drying equipment installation and mockup testing have been completed, and SNF drying is expected to begin in June 1997 [6].

SNF will first be loaded into new self-draining stainless steel buckets underwater and transferred via a shielded transfer car into an existing dry handling cave adjoining the basin. The buckets will be remotely loaded into new 18-inch OD by 11 -foot-long stainless steel canisters. Eighteen to twenty-one canisters will be utilized to store the SNF. Each canister is expected to contain no more than 3 liters $(0.8 \mathrm{gal})$ of water after loading [7]. The loaded canister will be sealed with a temporary lid and connected to vacuum and purge lines. The lid has two thermocouples and a pressure transducer to monitor SNF drying. 
The canisters will be heated and vacuum dried at a newly constructed station inside the fuel handling cave [8]. A 5 horsepower Leybold Sogevac SV100 single-stage rotating vane pump with an oil-sealed pumping chamber will be utilized. Pump capacity is $66 \mathrm{cfm}$ with a base pressure of 0.4 torr $(0.008 \mathrm{psia})$. The pump will be operated with air ballast to reduce water vapor condensation within the oil. HEPA filters in the vacuum pump suction line will capture micron size and larger corrosion products. A valve in the vacuum pump suction line will be throttled to maintain canister pressure above -5 torr $(0.10 \mathrm{psia})$ and prevent freezing. The pump is located in an accessible room and connected to the canister via $\sim 70$ feet of 1 -inch piping.

The canister drying well contains nine 1.5 kilowatt electric band heaters. The heaters will be cycled to maintain the canister internal temperature at $50^{\circ} \mathrm{C}$ during drying. The band heaters will also be utilized during subsequent baking of the fuel canister at $150^{\circ} \mathrm{C}$.

The canisters will be evacuated below 4.5 torr to ensure free liquid water has been vaporized. The vacuum pump will then be isolated, and the canister interior pressure will be monitored for 1-2 hours to confirm dryness. The pressure will rise if moisture is escaping from beneath the cladding or the canister system is leaking. The canister will be leak checked and/or dried again if the pressure rises during the evaluation period.

Uranium metal SNF will be conditioned after vacuum drying to remove some of the chemically-bound waters of hydration in the aluminum oxide. High temperature conditioning will also passivate uranium hydride corrosion products as described earlier. The SNF will be purged for two hours with $\sim 1 \mathrm{scfm}$ of argon containing $2 \%$ oxygen while baking at $150^{\circ} \mathrm{C}$.

A vented storage lid will be installed on the SNF canister after completion of drying and conditioning. The canister will be transported via an overhead crane into the Irradiated Fuel Storage Facility adjoining the CPP 603 Basin. This facility was originally constructed in 1974 for dry storage of graphite reactor fuel canisters. The SNF canisters will remain vented to atmosphere during extended storage in this facility. The oxygen content of air will promote oxide formation rather than hydride formation on exposed uranium during storage. 


\subsection{INEEL Three Mile Island SNF}

A program is also underway at INEEL to transfer 343 cans of Three Mile Island (TMI) Unit 2 core rubble into dry storage [9]. The cans are currently filled with water and stored in the Test Area North Basin. Each can will be partially dewatered by injecting nitrogen gas to expel bulk water through existing ports in the lid. The cans are expected to retain 20 to 250 pounds of water intermingled with debris and trapped inside the lower head after dewatering. Vectra is currently performing vacuum drying tests to develop a technique for removing residual water. A $300^{\circ} \mathrm{C}$ drying process to dehydrate rubble and low density concrete liners inside the cans is being considered.

Dried cans will be temporarily sealed for transport and loaded into 29 NUHOMS dual purpose canisters for subsequent transport and storage. Each dual purpose canister holds twelve TMI cans. The canisters will be placed into passively-cooled dry storage modules and vented to prevent potential hydrogen gas buildup. Similar NUHOMS canisters and storage modules are used at commercial nuclear reactors for SNF storage.

\subsection{Proposed INEEL Dry Storage Facility}

INEEL has prepared a conceptual design proposal for a major new SNF dry storage facility to hold $\sim 12,000$ assemblies [10]. The new facility will receive, package, and store Fort St. Vrain, Shippingport Light Water Breeder Reactor, Peach Bottom, TRIGA, and other miscellaneous SNF assemblies from the INEEL storage basins and offsite research reactors. Assemblies will be loaded into dry handling buckets and placed into $\sim 78$ NUHOMS dual purpose canisters similar to the TMI units. Each canister is $\sim 67$ inches OD and $\sim 186$ inches long. Canisters will be loaded inside a hot cell and closed by installing and welding ported shield plugs.

The canisters will be vacuum dried and inerted prior to long term storage. Development of the vacuum drying process has not proceeded beyond a conceptual description. The preliminary facility design report recommends an oil-cooled pump with filters on the pump inlet and outlet. The proposed canister dryness test is similar to tests described above. The canister will be evacuated until the internal pressure is below the triple point of water. Canister pressure will be monitored after isolating the vacuum pump, and leak checks or additional drying will be performed if the pressure rises. 
Each canister will be backfilled with inert gas and sealed by installing a second welded lid. The sealed canisters will be placed inside NUHOMS storage modules on a pad adjacent to the Chemical Processing Plant.

Development of a FY 1998 budget line item for the INEEL dry storage project has been halted. Privatization of the facility is currently being considered. The INEEL Spent Nuclear Fuel Task Team recently recommended consideration of smaller co-disposal canisters to facilitate eventual disposal within the geologic repository [11].

\subsection{PRIOR SRS DRYING PROGRAMS}

Lessons from two significant vacuum drying projects completed during deactivation of SRS reactor facilities are applicable to SNF drying. Unirradiated production reactor SNF and primary coolant loop heat exchangers were vacuum dried to remove or recover residual water.

\subsection{Unirradiated SNF}

Several hundred unirradiated Mark 22 fuel assemblies were removed from $P$ and $L$ Reactors and dried prior to deactivation of these facilities. The fuel assemblies contained four aluminum clad tubes, -14.5 feet long and 3.7 inches OD, nested inside an aluminum sleeve housing. Each fuel assembly was separated from the sleeve housing inside a tank of deionized water and placed into an aluminum storage canister. The canisters were heated and vacuum dried at a temporary station inside the reactor room [12]. The station was equipped with four heated fuel canister cradles and two 1.5 horsepower Welch model 1397 oil-sealed vacuum pumps. Pump capacity was $17.7 \mathrm{cfm}$ with a base pressure of 0.0001 torr. Each pump was connected to two canisters via 3/4-inch suction tubing and discharged into the reactor room ventilation exhaust duct. Sixteen strip heaters mounted on each canister cradle generated 1.9 kilowatts. The average cradle temperature was $\sim 200^{\circ} \mathrm{F}$.

Two fuel canisters were evacuated simultaneously with an average drying time of $\sim 40$ minutes and a final canister pressure of $\sim 3.5$ torr. Water accumulated inside the vacuum pump oil reservoir during drying, and frequent oil changes were necessary. The volume of water removed from the assemblies could not be measured, and no estimates are available. 


\subsection{Reactor Heat Exchangers}

An extensive vacuum drying program was conducted during final lay-up of $\mathrm{P}, \mathrm{L}, \mathrm{C}$, and K Reactor equipment in 1992-1995. Sixty two primary coolant loop heat exchangers were vacuum dried during 2-1/2 years to recover $\sim 5700$ gallons of $\mathrm{D}_{2} \mathrm{O}$ and remove several thousand gallons of contaminated $\mathrm{H}_{2} \mathrm{O}$. Each heat exchanger is 33 feet long and 8 feet in diameter with a total interior volume of $\sim 977$ cubic feet. The heat transfer surface is $\sim 33,400$ square feet.

New $300 \mathrm{cfm}$ Kinney vacuum pump skids were utilized in the heat exchanger drying program [13]. Each skid had a liquid-sealed vacuum pump coupled with an air ejector and booster blower. The liquid ring vacuum pump evacuated air from the heat exchanger and also served as a direct contact condenser for the moisture laden air. The pump was cooled by circulating antifreeze solution through an external heat exchanger and an air-cooled chiller.

A $1000 \mathrm{cfm}$ Edwards rotary vane oil-sealed vacuum pump and blower were connected in parallel with the Kinney skid to expedite final drying. The Edwards pump was utilized at $\sim 1$ torr after the Kinney pump had removed most of the water. A 20 kilowatt air heater/blower and seven 6 kilowatt radiant heaters warmed the tube bundle, heads, and shell during drying.

Multiple vacuum gages were installed to monitor heat exchanger pressure and vacuum pump inlet pressure. Heat exchanger shell and head temperatures were also monitored. Thirty one parameters on the vacuum drying equipment and heat exchanger were checked and recorded every 30 minutes. Each heat exchanger was vacuum dried until condensate removal ceased and a vessel pressure of 0.9 torr $(0.02$ psia) or lower was achieved. The last eleven heat exchangers dried contained an average of 209 gallons of water each before drying, and the average drying time was 193 hours each. 


\subsection{STORAGE CRITERIA FOR ALUMINUM SNF}

Acceptance criteria for 50-year dry storage of aluminum SNF were published in 1996 [1]. Specific acceptance criteria for aluminum SNF include:

- $\quad 200^{\circ} \mathrm{C}$ cladding temperature limit during drying and storage.

- Drying temperature may be increased to $250^{\circ} \mathrm{C}$ for 2 hours on SNF with non-breached cladding.

- No more than 1 milliliter of free water per 0.1 square meter of cladding surface.

- Sealed storage in nonreactive gas, air, vacuum, or

- Non-sealed storage with flowing ambient air around SNF.

These criteria were established to limit general corrosion and pitting to 0.003 inches and local deformation (creep) to 0.1 inch. Sealed canisters are recommended for road-ready interim dry storage [14].

\subsection{Aluminum SNF Corrosion}

Three sources of water potentially contribute to corrosion of aluminum SNF:

- Free water on the SNF surface and in pits, crevices, etc.

- Water of hydration within the aluminum oxide surface coating.

- Adsorbed water on the surface of aluminum metal or oxide.

The acceptance criteria of 1 milliliter of free water per 0.1 square meter of surface could leave enough residual moisture to generate $\sim 0.0001$ inch of uniform aluminum corrosion [1]. A protective film of hydrated aluminum oxide (Boehmite) forms as aluminum cladding reacts with water vapor. This oxide could eventually dehydrate during SNF storage; however, release of water from a 50 micron thick film of Boehmite is predicted to generate only 0.00026 inch of corrosion. Adsorbed water is much less than the water of hydration and is a negligible concern. 
Calculated water contributions from each source on a cropped 18-plate MTR assembly (Appendix C), and predicted corrosion losses are:

Source

Free water

Water of hydration

Adsorbed water

\section{Criteria}

$<1 \mathrm{ml}$ per $0.1 \mathrm{~m}^{2}$

50 microns thick

20 molecular layers
$\underline{\mathrm{H}_{2}} \underline{\mathrm{O}}$

$16.6 \mathrm{gm}$

$42.6 \mathrm{gm}$

$<0.02 \mathrm{gm}$
Corrosion

0.0001 in 0.00026 in negligible

\subsection{Hydrogen and Hydride Buildup}

Buildup of hydrogen inside a sealed SNF storage container is another potential concern. Hydrogen gas is released as water and aluminum react to form Boehmite. The explosive range of hydrogen in air is $4 \%$ to $75 \%$ by volume at room temperature. The SNF canisters will likely be backfilled with an inert gas prior to sealing, but air will be introduced if the canisters are reopened for inspection/fuel characterization prior to placement inside the repository. In addition, 10 CFR 60.135(b)(1) prohibits explosive materials inside repository waste packages in amounts that could compromise waste isolation or performance objectives. The $4 \%$ hydrogen threshold equates to -17 grams of free water inside a 17-inch diameter by 10-foot long storage canister if the water fully reacts with aluminum to form hydrated oxide and release hydrogen. The water limit for hydrogen buildup is more restrictive than the corrosion limits cited above (Appendix D). Evaluation of engineering options for mitigation of hydrogen buildup is continuing.

Hydrides are not expected in corroded uranium-aluminum SNF because uranium is bound as a $\mathrm{UAl}_{\mathbf{X}}$ aluminide. The aluminide is a stable compound and is dispersed in a matrix of aluminum which prevents uranium and hydrogen from reacting readily. The aluminum oxide film on the SNF cladding is not a pyrophoric hazard because it forms slowly, is relatively thin, and generates minimal heat during formation. Bureau of Mines tests reportedly indicate aluminum powder must reach $-500^{\circ} \mathrm{C}$ to ignite. 


\subsection{ALUMINUM SNF DRYING}

A SNF dry handling and storage facility proposed in late 1996 per Project S-7703 would have included drying equipment [15]. The current Request for Proposal for SNF handling and storage services does not specify wet versus dry SNF handling, but a vacuum drying system could be adapted to either handling mode. SNF could be dried before or after loading the storage canisters if a dry handling system is selected. A 17.5-inch diameter by 12 -foot long drying chamber would accommodate the largest bare aluminum SNF currently planned for receipt at SRS. Drying prior to canister loading is feasible because water adsorbed on the SNF surface after initial drying is a negligible corrosion concern as described earlier.

\subsection{Water Volume Estimate}

The initial volume of free water inside an SRS SNF canister can not be accurately estimated without testing. A 17-inch-diameter by 10 to 15-foot-long co-disposal canister has been proposed. Hanford and INEEL SNF canisters of comparable size are expected to contain about one gallon of water that must be removed by vacuum drying.

Water retention can be conservatively estimated at 0.5 gallons per assembly by assuming all annuli in a cropped 18-plate MTR assembly are plugged at the bottom with debris and filled with water (Appendix B). Rough drying time estimates with this initial water loading are:

\section{Drying Method}

Hanford system @ $0.16 \mathrm{gal} / \mathrm{hr}$ INEEL system @ $0.40 \mathrm{gal} / \mathrm{hr}$ SRS heat exchanger system @ $1.08 \mathrm{gal} / \mathrm{hr}$

\section{One Assembly}

$3.1 \mathrm{hrs}$

$1.3 \mathrm{hrs}$

$0.5 \mathrm{hrs}$

\subsection{Drying Test Program}

A test program is highly desirable to quantify drying system performance for SRS SNF. Initial tests should focus on drying dummy test assemblies with various free water contents. Dummy assemblies can be dried and monitored inside instrumented canisters to check drying effectiveness. Some non-radiologically contaminated drying equipment is still available from the reactor heat exchanger vacuum drying program and can be utilized in this test program. 
Vacuum drying should be integrated into the test program for placing irradiated MTR assemblies into instrumented dry storage canisters in L Area. This test will build upon drying experience gained with the dummy assemblies. Radiologically contaminated vacuum pumps and heaters from the reactor heat exchanger drying program could be used to dry the MTR assemblies.

Heated forced air drying may provide effective removal of gross water from SNF prior to vacuum drying or serve as an alternative to vacuum drying. Hot air (130-150 F) would be blown across the SNF assembly plates to evaporate surface moisture. Further analysis and experimentation is required to evaluate this concept.

\subsection{REFERENCES}

1. R. L. Sindelar, H. B. Peacock, Jr., P. S. Lam, N. C. Iyer, and M. R. Louthan, Jr., Acceptance Criteria for Interim Dry Storage of Aluminum-Alloy Clad Spent Nuclear Fuels, WSRC-TR-95-0347, March 1996.

2. S. L. Robinson and G. J. Thomas, Uranium Hydride Formation and Properties: A Review with Commentary on Handling and Disposition, SAND96-8206, January 1996.

3. Performance Specification for the K-Basin SNF Vacuum Drying Module (draft), 1995.

4. Communication with J. J. Irwin, Hanford Vacuum Drying System Design Authority Engineer, 2/10/97.

5. K. M. Wendt, Dry Canning and Interim Dry Storage of Selected CPP-603 Fuels (presentation), October 26, 1995.

6. Communication with M. A. Ebner, INEEL, 2/6/97.

7. Idaho Chemical Processing Plant Technical Safety Document (draft revision 2A), WIN-107-4.12, October 20, 1995.

8. K. M. Wendt, Successful Deployment of the Fuel Canning Station at the Idaho National Engineering Laboratory (draft), August 1996. 
9. Performance Specification - ICPP Interim Storage System for the Long Term Storage of TMI-2 Fuel, Project No. 93-E-900, February 1995.

10. Conceptual Design Report for the ICPP Spent Nuclear Fuel Dry Storage Project, INEL-96/0182, July 1996.

11. Technical Strategy for the Management of INEEL Spent Nuclear Fuel, Volume I, March 1997.

12. K. T. Counts, T. N. Riley, and D. W. Bickley, P Area Defueling - MK22 Drying System, RRD-ROCH-910175, July 12, 1991.

13. W. S. Large and R. H. Sears, $\underline{C}$ Area Heat Exchanger Vacuum Drying, EFR-EFS-96-0019, March 20, 1996.

14. R. L. Sindelar, et. al., Alternative Aluminum Spent Nuclear Fuel Treatment Technology Development Status Report, WSRC-TR-97-0084, April 1997.

15. Facility Design Description for the SRS Spent Nuclear Fuel Transfer and Storage Facility, M-FDD-G-00001, November 18, 1996. 


\begin{tabular}{|c|c|c|c|c|c|}
\hline & $\begin{array}{c}\text { Hanford K Reactor } \\
\text { Basins }\end{array}$ & INEEL TMI-2 & $\begin{array}{c}\text { INEEL CPP Dry } \\
\text { Storage Project }\end{array}$ & $\begin{array}{l}\text { INEL CPP-603 AL-Clad } \\
\text { \& Sodium-Bonded SNF }\end{array}$ & SRS \\
\hline Fuel & $\begin{array}{c}100,000 \\
\text { Zirc clad U metal assys } \\
2.42 " \text { OD, 26.1" long } \\
51.6 \mathrm{lbs} \text { per assy } \\
1.25 \%{ }^{235} \mathrm{U} \text { max }\end{array}$ & $\begin{array}{l}\text { Core rubble } \\
2.95 \%{ }^{235} \mathrm{U}\end{array}$ & $\begin{array}{c}>4000 \text { TRIGA } \\
\text { assemblies, } \\
744 \text { FSV assemblies, } \\
\text { plus Shippingport, } \\
\text { Peach Bottom, and misc } \\
\text { SS \& Zirc clad SNF }\end{array}$ & $\begin{array}{l}\text { Seven fuel types incl. } \\
\mathrm{UAl}, \mathrm{UZ \textrm {rH }} \text {, UO } 2 \text {, } \\
\mathrm{U}_{3} \mathrm{O} 8, \mathrm{U} \text { metal assys } \\
\text { and } 220 \mathrm{~kg} \text { U flux filter. } \\
12^{\prime \prime} \text { to } 50^{\prime \prime} \text { long plates } \\
\text { and } 28{ }^{\prime \prime}-37^{\prime \prime} \text { long rods } \\
5.3 \%-93.5 \% 235 \mathrm{U}\end{array}$ & $\begin{array}{l}\text {-34,000 Al-clad } \\
\text { uranium-aluminum } \\
\text { alloy assys }\end{array}$ \\
\hline $\begin{array}{c}\text { Canister } \\
\text { Materials \& } \\
\text { Dimensions }\end{array}$ & $\begin{array}{l}\text { 304L SS MCO with } \\
\text { removable baskets } \\
24 \text { " OD Std wght pipe } \\
25.25 " \text { OD shield plug } \\
166 " \text { long, 148" cavity }\end{array}$ & $\begin{array}{c}\text { Existing 304L/316L } \\
\text { stainless steel cans } \\
\text { are } 14 " \text { OD, } 150 " \text { long } \\
3 \text { can designs: Fuel } \\
\text { Filter } \\
\text { Knockout } \\
\text { Cans will be stored } \\
\text { inside Vectra DPC's }\end{array}$ & $\begin{array}{l}304 / 316 S S(?) \text { Vectra } \\
\text { FO-DPC is } 67.25^{\prime \prime O D} \text {, } \\
66^{\prime \prime} \text { ID, } 186.2^{\prime \prime} \text { long } \\
\text { with } 167^{\prime \prime} \text { cavity. } \\
\text { Peach Bottom SNF cans } \\
\text { are } 12.75^{\prime \prime O D}, 166^{\prime \prime} \\
\text { long, } 161.5^{\prime \prime} \text { cavity }\end{array}$ & $\begin{array}{l}\text { SS canisters with } \\
\text { removable buckets. } \\
\text { Canisters are } 11 \mathrm{ft.} \text { long } \\
18 \text { " OD Sch } 10 \text { pipe }\end{array}$ & $\begin{array}{l}\text { SS canister } \\
<17.7^{\prime \prime} \mathrm{OD} \\
<179.9 \text { " long }\end{array}$ \\
\hline Closure & $\begin{array}{l}\text { Threaded shield plug } \\
\text { with O-ring and } 4 \text { ports } \\
\text { Welded cap over plug? }\end{array}$ & $\begin{array}{l}\text { Bolted (1) and welded } \\
\text { can lids with } 1 / 4 " \text { \& } 3 / 8 " \\
\text { couplings for venting }\end{array}$ & Welded & $\begin{array}{l}\text { Vented lid secured with } \\
\text { lever arm }\end{array}$ & \\
\hline Weight & $\begin{array}{c}19,142 \text { lbs dry } \\
\text { ( } 288 \text { assemblies max })\end{array}$ & $\begin{array}{l}2800 \text { lbs max dewatered } \\
\text { per can }\end{array}$ & & & \\
\hline Quantity & 400 MCO's & 343 cans in 29 DPC's & $\sim 78$ DPC's & 18 to 21 canisters & \\
\hline Heat Load & $\begin{array}{l}400 \text { watts nominal } \\
800 \text { watts max } \\
\text { per MCO }\end{array}$ & $\begin{array}{l}20 \text { watts avg } \\
80 \text { watts max } \\
\text { per TMI can }\end{array}$ & & $\begin{array}{l}<300 \text { watts per canister } \\
\text { (12 watts per ATR assy) }\end{array}$ & $\begin{array}{l}<14.2 \text { kilowatts } \\
\text { per canister }\end{array}$ \\
\hline Design Rating & $\begin{array}{l}\text { ASME Sec III, Sub NB } \\
150 \text { psig, } 200^{\circ} \mathrm{C}\end{array}$ & $\begin{array}{l}\text { ASME Sec VIII, Div I } \\
140 \mathrm{psig}, 400^{\circ} \mathrm{F}\end{array}$ & $\begin{array}{l}\text { Not established for DPC } \\
\text { Peach Bottom cans rated } \\
\text { @ } 15 \text { psig, } 380^{\circ} \mathrm{C}\end{array}$ & & \\
\hline $\begin{array}{l}\text { Free Water } \\
\text { Inside } \\
\text { Canister } \\
\text { Before Drying }\end{array}$ & $\begin{array}{l}2-4 \text { liters }(0.5-1 \text { gal) per } \\
\text { MCO expected } \\
\text { 16. liters }(4.2 \text { gal) max } \\
\text { capacity }\end{array}$ & $\begin{array}{l}\text { 20-250 lbs (2.4-30 gal) } \\
\text { per "filter" can }\end{array}$ & & 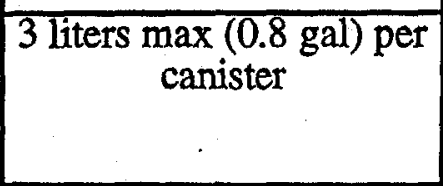 & \\
\hline $\begin{array}{l}\text { Radiation } \\
\text { Rate }\end{array}$ & & $\begin{array}{c}1500 \mathrm{R} / \mathrm{hr} @ 1 \mathrm{~cm} \text { from } \\
\text { top of can }\end{array}$ & $\begin{array}{c}300 \mathrm{mR} / \mathrm{hr} @ \text { top of } \\
\text { DPC }\end{array}$ & & \\
\hline
\end{tabular}




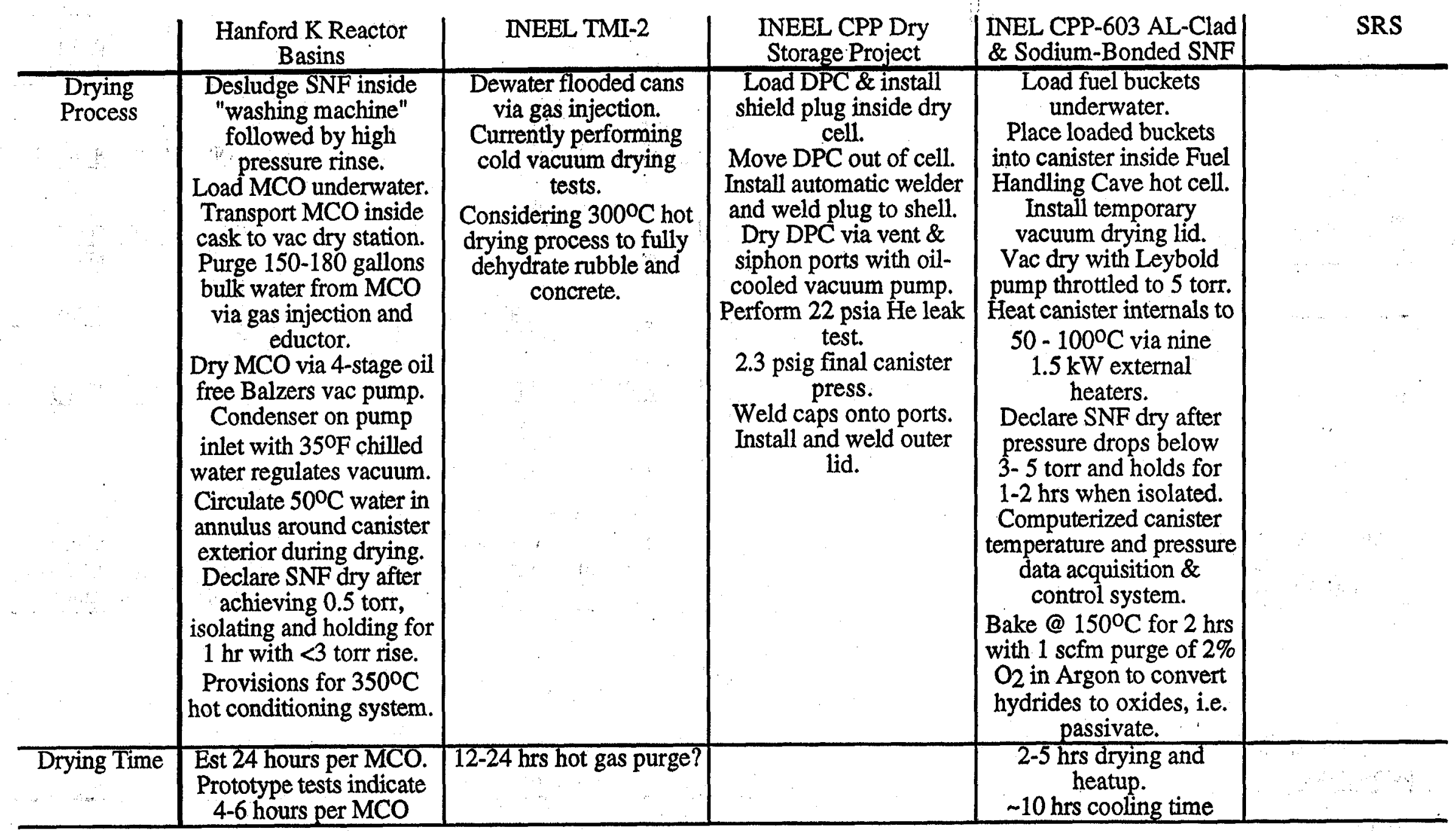




\begin{tabular}{|c|c|c|c|c|c|}
\hline . & $\begin{array}{c}\text { Hanford K Reactor } \\
\text { Basins }\end{array}$ & INEEL TMI-2 & $\begin{array}{c}\text { INEEL CPP Dry } \\
\text { Storage Project }\end{array}$ & $\begin{array}{l}\text { INEL CPP-603 AL-Clad } \\
\text { \& Sodium-Bonded SNF }\end{array}$ & SRS \\
\hline Storage Mode & $\begin{array}{l}\text { Canister Storage Bldg } \\
\text { similar to Fort St Vrain } \\
\text { modular vault dry } \\
\text { storage facility. }\end{array}$ & $\begin{array}{l}\sim 29 \text { DPC's holding } 12 \\
\text { TMI cans each. } \\
\text { Vented DPC's stored in } \\
\text { NUHOMS modules } \\
\text { with passive cooling. }\end{array}$ & $\begin{array}{l}78 \mathrm{DPC} \text { 's stored in } \\
\text { NUHOMS modules } \\
\text { with passive cooling. }\end{array}$ & $\begin{array}{l}\text { Irradiated Fuel Storage } \\
\text { Facility in CPP. } 603 \text {. } \\
\text { Exhaust fan online, but } \\
\text { not required for cooling. } \\
80-90^{\circ} \mathrm{C} \text { inside canister. }\end{array}$ & $\begin{array}{l}\text { Modules or } \\
\text { Monolith }\end{array}$ \\
\hline Concerns & $\begin{array}{l}\text { Self ignition of hydrides } \\
\text { on severely corroded } \\
\text { assemblies during } \\
\text { handling. } \\
\text { Hydrides swell cladding } \\
\text { allowing evolved } \mathrm{H}_{2} \text {, } \\
\mathrm{O}_{2} \text { to escape and } \\
\text { pressurize MCO. }\end{array}$ & $\begin{array}{c}\text { Radiolysis of residual } \\
\text { moisture may lead to } \\
\mathrm{H}_{2}, \mathrm{O}_{2} \text { generation and } \\
\text { pressurization of cans } \\
\text { while sealed during } \\
\text { transport. } \\
\text { Criticality analyses very } \\
\text { conservative because } \\
\text { there is no record of } \\
\text { fissile content per can. }\end{array}$ & $\begin{array}{l}\text { Corrosion \& radiolysis } \\
\text { lead to DPC gas } \\
\text { pressurization. }\end{array}$ & $\begin{array}{l}\text { Uranium hydride is } \\
\text { pyrophoric and could } \\
\text { ignite U metal SNF. } \\
\text { Water released during } \\
\text { storage decomposes into } \\
\mathrm{H} 2, \mathrm{O}_{2} \text { leading to } \\
\text { hydride formation. }\end{array}$ & \\
\hline Status & $\begin{array}{c}\text { Start loading MCO's } \\
\text { between } 12 / 97 \text { and } 5 / 98 \text {. }\end{array}$ & $\begin{array}{l}\text { Contract awarded to } \\
\text { Vectra in Summer } 1996 .\end{array}$ & $\begin{array}{l}\text { Privatize per } 1 / 97 \\
\text { decision. }\end{array}$ & $\begin{array}{l}\text { Field installation tested } \\
\text { with mockup fuel in } \\
\text { Summer } 1996 . \\
\text { Passivation procedures } \\
\text { require revision. } \\
\text { Start SNF drying by } \\
\text { June } 1997 . \\
\end{array}$ & $\begin{array}{l}\text { Request for } \\
\text { Proposal under } \\
\text { development. }\end{array}$ \\
\hline Regulations & DOE Orders & 10 CFR 72 & 10 CFR 72 & DOE Orders & 10 CFR 72 \\
\hline
\end{tabular}


APPENDICES 
$\operatorname{Cos} 2 \operatorname{10} 10$ Rev G-18-92

ENGINEERING COMPUTATION SHEET

WSRC-TR-97-0075

Tile of Project Determine mass of water vapor Procectro. Appendix A inside Hanford MCO after drying works to 3 torr computer WS Large Date $\quad 3 / 17 / 97$ Sheet Ne. A.

Estimate volume of free water inside MC O with final internal pressure of 3 torr.

$$
3 \text { tor }=0.0580 \text { psia }
$$

assume MCO ha o no leaks and internal presolve is due entirely to reavdual water vapor.

$$
\therefore \text { P water }=0.0580 \text { psid }
$$

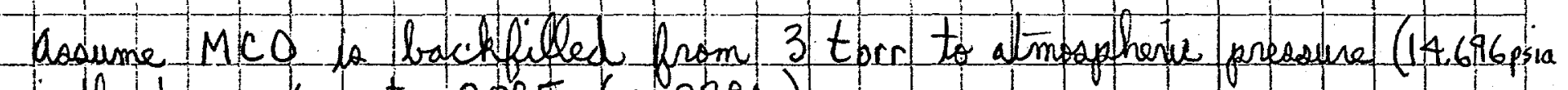
with ding air at $80^{\circ} \mathrm{F}\left(227^{\circ} \mathrm{C}\right)$.

$$
P_{\text {sat }}=0.50736 \text { psia } @ 80 \text { F }
$$

The water content in unchanged as the MCO is bacffielled with dry bins.

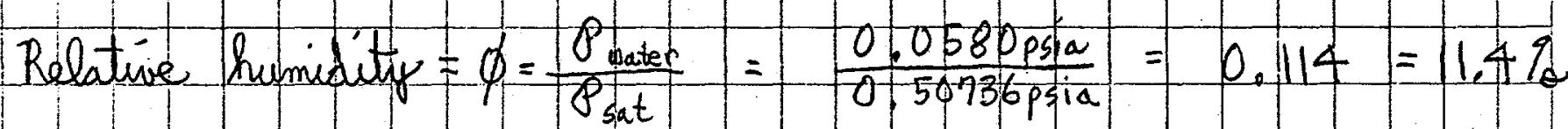

$$
\begin{aligned}
& \text { Humidity ratio }=W=0.62198 \frac{\text { vapor }}{\text { PEtal }- \text { vapor }} \text { P. } 6.2 \text { ASHRAE Fund } \\
& =W=0.62198\left(\frac{0.0580}{1.496-0.0580}\right)=0.00246
\end{aligned}
$$


OSR 25-10 (Rev 6-18-92)

ENGINEERING COMPUTATION SHEET

Title of Project

Project No.

RS

Subject

Works

WSL Date $\quad 3 / 17 / 97$

Sheet NomA 2

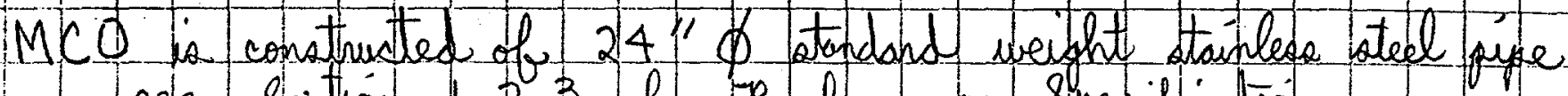
fer section 1.2.3 of Performance specification

$M C O$ is $\sim 148$ ' long internally per SK -2-30046

$$
\begin{aligned}
& M \angle D \text { ID }=\frac{23.500^{\prime}}{I A=} \text {. for } 24^{\prime \prime} \operatorname{Sch} 10 \mathrm{St} \\
& \text { Vol }{ }_{\text {eCO }}=\text { area *height }=3.0121 \mathrm{ft}^{2} * 148 / 12 \mathrm{ft}=37.149 \mathrm{ft}
\end{aligned}
$$

MCO is loaded with 288 Mark I A fuel assemblies.

Fuel Ass Dimensions:

$2.425 " O D>7$ outer tube

$1.701^{\prime \prime}$

$26.10^{\prime \prime}$

$1.279^{\prime \prime}$ OD 2 inner tube

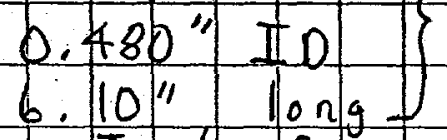

$$
\begin{aligned}
& \text { Area }=\pi / 4\left(O D^{2}-I D^{2}\right)_{\text {cuter }}+\pi / 4\left(0 D^{2}-I D^{2}\right)_{\text {Inter }} \\
& =\pi / 4\left(2.425^{2}-1.701^{2}\right)+\pi / 4\left(1.2792-0.480^{2}\right) \\
& =2.346 \mathrm{in}^{2}+1.104 \mathrm{in}^{2}=3.450 \mathrm{im}^{2} \\
& \text { Volume }=3.44999 \mathrm{in}^{2}+26.10 \mathrm{in}=90.05 \mathrm{in}^{3} \\
& \text { ane Ass } \\
& V_{\text {volume }} \text { Assays }_{288}=90.05 \mathrm{in}^{3} * 288=25932 . \mathrm{in}^{3}=15.007 \mathrm{ft}^{3}
\end{aligned}
$$

$$
\begin{aligned}
& \text { Free Volume inside } M C O=\text { Gross Vol - Volume of } 288 \text { Assays } \\
& =37.149 \mathrm{ft}^{3}-15.007 \mathrm{ft}^{3} \\
& =22.142 \mathrm{ft}^{3}
\end{aligned}
$$


$\cos x-10(\operatorname{Rev}(-18-92)$

ENGINEERING COMPUTATION SHEET

Tie or Project

Project No.

Subject

Woke

Computer

Dais

$3 / 17 / 97$

SOS

WIS

Sheet NaPA 3

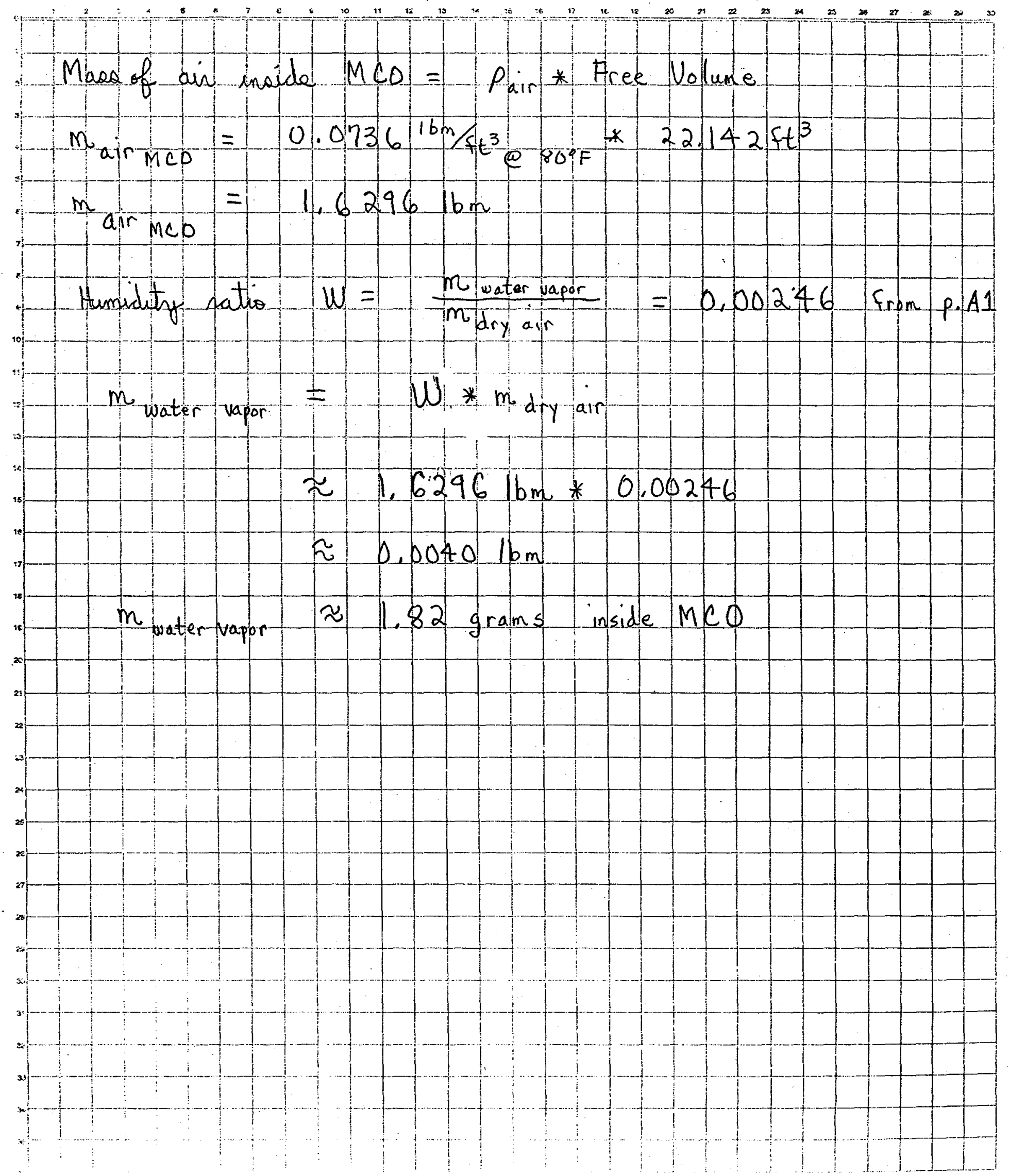


ASA $2 \dot{-1 n}$ (her 6-18-92)

ENGINEERING COMPUTATION SHEET

WSRC-TR - 97-0075

This of Project Determine surface area of cropped Proper No. Appendix B

subject RINC MTR assembly

Works

Computer

WSL Date

$3.12 / 97$

Sheet No. B

Length of copped doubly $=25.5 "$ per $7 / 18 / 85$ Appendix $A$ data for Rhode leland nuclear science center

18 fuel plates per assembly with minimal dimensions of $25.00^{\prime \prime}$ by $2.810^{\prime \prime}$ by $0.060^{\prime \prime}$ thick per EGG dug $4 \| 1641$

Each fuel plate fits into side plate slots.

Exposed width of fuel plate is $22.557 "$ per EGG dug 411650

Exposed surface area per fuel plate:

$$
\begin{aligned}
25.00^{\prime \prime} * 2.55 n^{\prime \prime} * 2 \operatorname{sanfaces} & =22.85 \mathrm{in}^{2} \\
0.1060^{\prime \prime} * 2.557^{\prime \prime} * 2 \text { ends } & = \pm .31 \mathrm{in}^{2} \\
\text { Exposed plate area } & =128.1568 \mathrm{in}{ }^{2}
\end{aligned}
$$

Two aluminum side plates per assembly with nominal dimensions of 25.54 (cropped) by $3.045^{\prime \prime}$ by $0.188^{\prime \prime}$ thick per EGG dogs 411648 and 411650

Exposed surface area per aluminum side plates.

$$
\begin{aligned}
& \begin{array}{l}
25.5^{\prime \prime} * 3.045^{\prime \prime} * 1 \text { outside surface } \\
0.188^{\prime \prime} * 3.045^{\prime \prime} * 2 \text { ends }
\end{array} \\
& =72.647 \mathrm{in}^{2}
\end{aligned}
$$

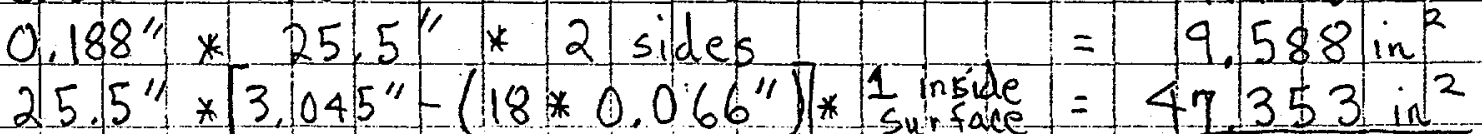

$$
\begin{aligned}
& =1.145 \mathrm{in}^{2} \\
& \text { Exposed side plate ares }=\frac{135.7339 \mathrm{il}^{2}}{2}
\end{aligned}
$$

Neglect fuel plate 0.5 " shorter than side plate for inside suffice adjustment 
Css 25-10 (Rev 6-18-92)

ENGINEERING COMPUTATION SHEET

This of Project

Project No.

PRS

Sties

Works

$3 / 17 / 97$

Shoe l No. Bo

Total surface area of RINC MTR assembly:

$$
\begin{aligned}
& 18 \text { fuel plates } * 128,157 \mathrm{in}^{2} / \text { plate }=2306,82 \mathrm{in}^{2} \\
& 2 \text { side plates } * 135.734 \mathrm{in}^{2} / \text { plate }=27147 \mathrm{in}^{2} \\
& \text { Total }=2578.29 \text { in }^{2} \\
& \text { Total }=17.90+t^{2} \\
& =1.663 \mathrm{~m}^{2}
\end{aligned}
$$

Determine vo rid volume between 18 fuel plates.

17) Slate between 18 plates

Each clot la 2 2.55?" wide by $25.00^{\prime \prime}$ high from bleat B1

Each slot is $2.910^{\prime \prime}-2.743^{\prime \prime}-0.060^{\prime \prime}=0.107^{\prime \prime}$ thick

per $E G G$ digs 411648 and 411647

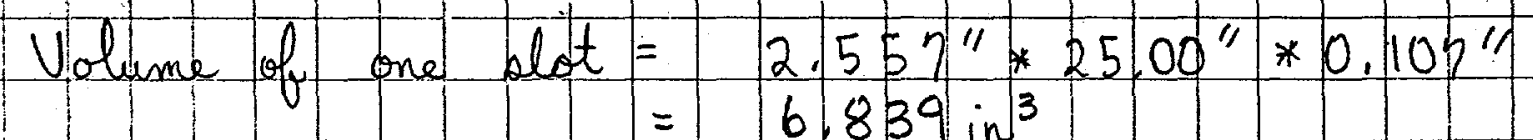

Volume of 17 plots $=116.274 \mathrm{in}^{3}$

$=0.50$ gallons 
OSR 25-10 (Rey 6-18-92)

Title of Project

ENGINEERING COMPUTATION SHEET

Subject

Project No.

Appendix B

$\mathrm{SRS}^{2}$

conouter WSL Works

$3 / 20 / 97$ sheet No. $B 3$

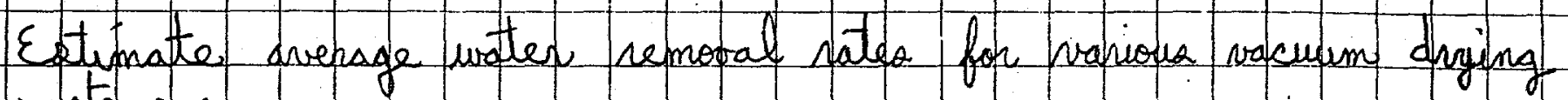
anstemot:

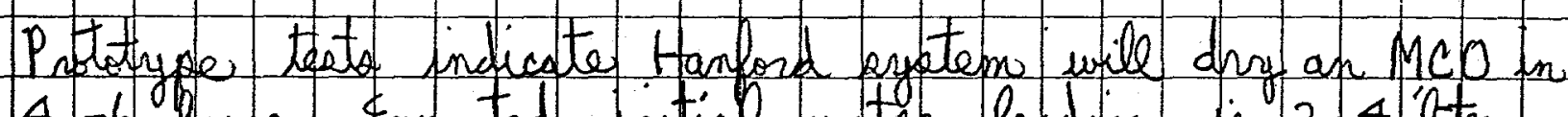
4-6 houra. Experted initial unater loading ia $2-4$ litera per diacuasion mith John Iruin on $2 / 10 / 97$.

$$
\begin{aligned}
\text { Sary average nemoval naté }= & 3 \text { liters in } 5 \text { houro } \\
& =0.16 \mathrm{gal} / \mathrm{hr}
\end{aligned}
$$

Expected drving teme for INEL cancoster ie $22 \mathrm{hn}$ per metez from $10 / 26195$ SNF Daning station Meeting.

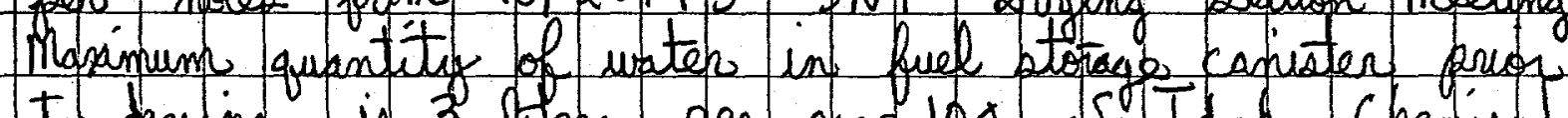
to drying is 3 felero per page 104 of I Iato Chenticat Processing Plant Saftety Document WIN-10 -4,12, Addendum B, Drast Revision 2 A.

$$
\begin{aligned}
\text { Lary avenage removal nate } & =3 \text { litera in } 2 \text { haves } \\
& =0.40 \mathrm{gal} / \mathrm{hr}
\end{aligned}
$$

566 gollona of $\mathrm{D}_{2} \mathrm{O}$ and 1736 gallons of $\mathrm{H}_{2} \mathrm{O}$ were hesovered from II $S R$ S hest exchanaero inaide Bldg $105-C$ via vacuume druing. Total elipoed vacuum arging time ure 2125 horera per "105-C Heat Exchanger Vacuum Anying Log. maintained by project engineer.

$$
\begin{aligned}
\text { Sang apreage nemoval nate } & =2302 \mathrm{gallone} / 2125 \mathrm{hrs} \\
& =1.08 \mathrm{gal} / \mathrm{hr}
\end{aligned}
$$


Cst $2-10$ (Rev 6-18-92)

ENGINEERING COMPUTATION SHEET

The of Project.

Determine mass of free water

Project No. Appendix C

Subject on cropped MTR assembly per Works drying criterion computer W.S.L Date $3 / 12 / 97$ Shoe t No. Cl

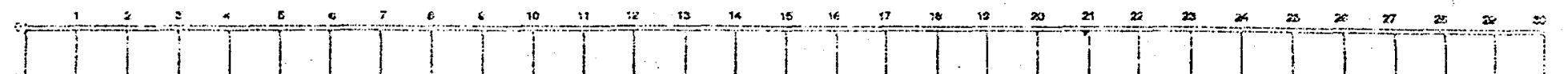

Assume assembly had been vacuum dried to acceptance criterion of $1 \mathrm{ml}$ free water for $0.1 \mathrm{~m}^{2}$ of surface per WSRC-TR-95-034\%.

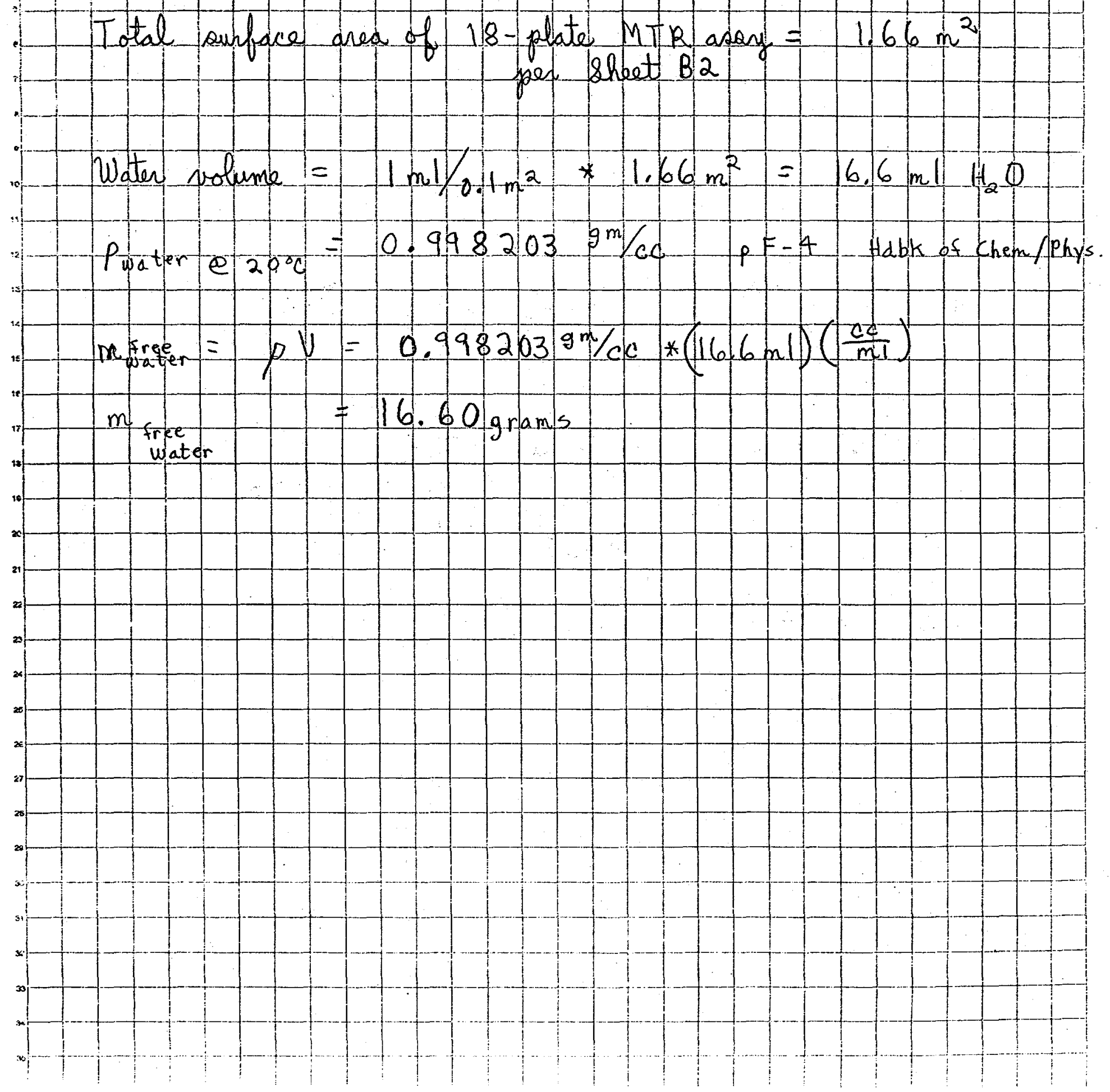


OSR 2S-10 (Rev 6-18̂-92)

Stoves: 26-15510.00

ENGINEERING COMPUTATION SHEET

Title of Project

Determine mass of adsorbed

Project No.

Subject water on cropped MTR assembly works Computer WSL Date

$3 / 12 / 92$

Sheet No. $\subset 2$

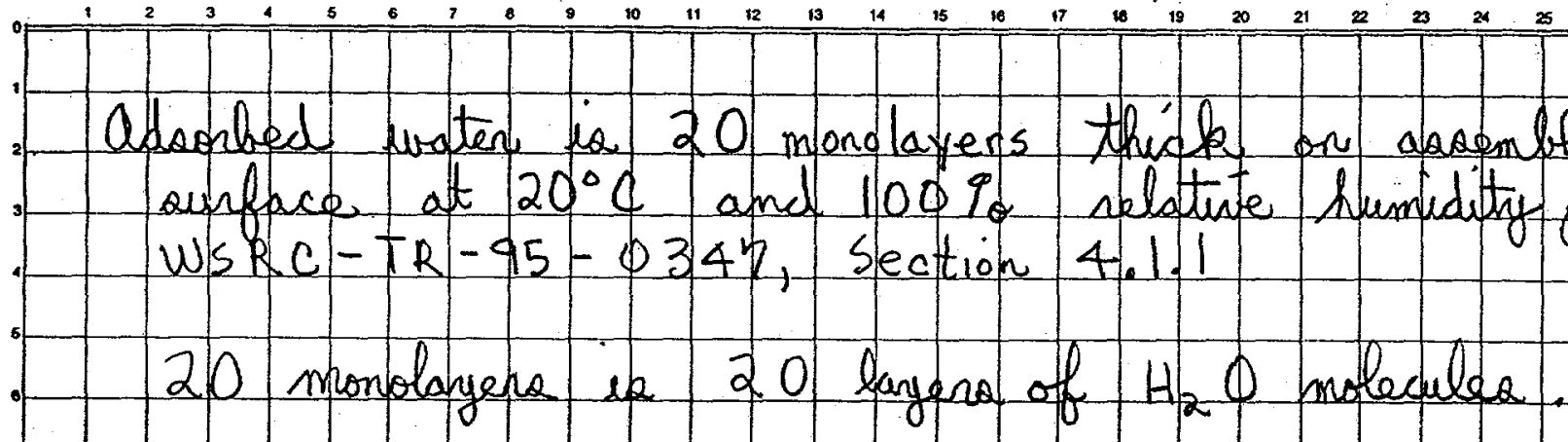

$\mathrm{H}_{2} \mathrm{O}$ molecular diameter $=4,60 \times 0^{-8} \mathrm{~cm}$ per atachell table

$\begin{aligned} 20 \text { layer thoknesa }= & =20 * 4.60 \times 10^{-8} \mathrm{~cm} \\ & =9.2 \times 10^{-7} \mathrm{~cm} \\ & =9.2 \times 10^{-9} \mathrm{~m}\end{aligned}$

Total enforce area of 18 plate M TR as $=1.66 \mathrm{~m}^{2}$ per sheet $\$ 2$

- Volume of water $=20$ larger thécness * surface area $=9.2 \times 10^{-9} \mathrm{~m} * 1.663 \mathrm{~m}^{2}$ $=1.53 \times 10^{-8} \mathrm{~m}^{3}$

$V_{\text {water }}=0.0153 \mathrm{cc}$

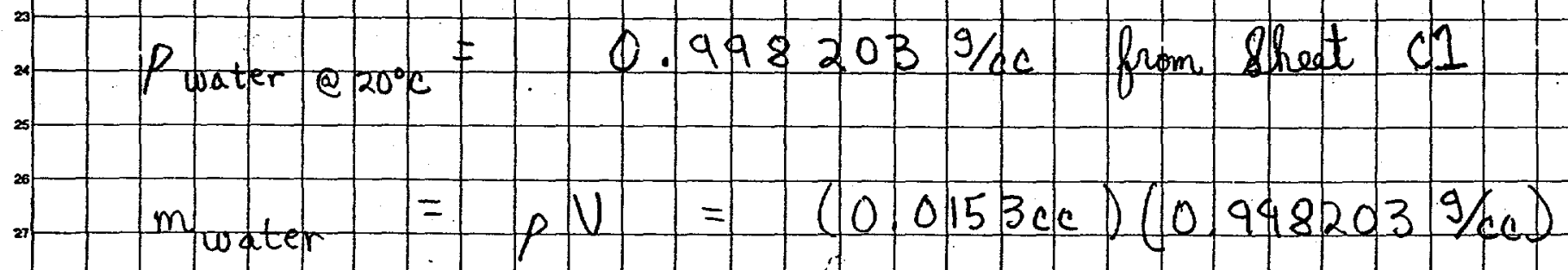

modsorbed $=$ water
0.015 grams

HUS. GPO: $1996-541-274$ 
$(Q)$ is also called throughput and is work per unit time ( $\underline{P V}$ ).

C. Ideal Gas Equation

$$
\begin{array}{ll}
P V=n R T \quad P & =\text { Torr } \\
V & =\text { Liters } \\
n & =\text { No. of Moles } \\
R & =\text { Molar Gas Constant } \\
T & =\text { Degrees Kelvin }
\end{array}
$$

or.

$$
\begin{array}{ll}
P V=n k T & P=\text { Dynes } \\
V & =c c \\
n & =\text { No. of Molecules } \\
\mathbf{k} & =\text { Boltzmann's Constant } \\
\mathbf{T} & =\text { Degrees Kelvin }
\end{array}
$$

D. Mean Free Path, for air

$$
L=\frac{5 \times 10^{-3}}{P_{\text {Torr }}} \text { in centimeters }
$$

E. Molecular Velocity

a) $\bar{V}=1.5 \times 10^{4} \sqrt{\frac{\mathrm{T}}{\mathrm{M}}} \mathrm{sec}^{-1}$

$$
T=K^{*}
$$

$M=$ Molecular Weight

b) $\bar{V}=\sqrt{8 \mathrm{KT}} \mathrm{cm} \mathrm{sec}^{-1}$

$$
\pi \mathrm{m}
$$

$k=$ Boltzmann's Constant

$T=K^{\circ}$

$m=$ Molecular Mass in Grams
F. Pumpdown (Roughing) Formulas, excluding outgassing

$$
\text { a) } P=P_{0} e^{\frac{-s t}{v}}
$$

$P_{0}$ in Torr (original pressure) $P$ in Torr $S$ in liters per second $V$ in liters

b) $t=\frac{V}{S}$ in $\frac{P_{0}}{P}$

\section{x. Common Values}

$$
\begin{aligned}
& \text { Acceleration-Gravity } \mathrm{g}=980.6 \mathrm{~cm} \mathrm{sec} \cdot 2 \\
& =32.174 \mathrm{Ft} \mathrm{sec}-2 \\
& \text { Angstrom Unit } \AA=10^{8} \mathrm{~cm} \\
& \text { Area Constant } \pi=3.1416 \\
& \text { Atornic Mass Unit AMU }=1.66 \times 10^{-24} \text { grams } \\
& \text { Avogadro's Number } n=6.023 \times 10^{23} \\
& \text { mols per mole } \\
& \text { Boltzmann's Constant } k=1.38 \times 10^{-16} \\
& \text { ergs-deg-1-molecule-1 } \\
& \text { Electron Charge } q=1.602 \times 10^{-19} \text { coulomb } \\
& \text { Mechanical } \\
& =8.31 \times 10 \text { ergs deg }^{-1} \text { mole }^{-1} \\
& =62.36 \text { Torr-Liter deg.1 } \\
& \text { mole-1 } \\
& \text { Molecular Diameter d } \cong 3 \AA \\
& \text { Natural Log Base } \theta=2.7183 \\
& \text { Velocity of Light } c=3 \times 10^{10} \mathrm{~cm} \mathrm{sec}^{-1} \\
& \text { Velocity of Molecule } \bar{v}=4.9 \times 10^{4} \mathrm{~cm} \mathrm{sec}^{-1} \\
& \text { (1100 MPH) }
\end{aligned}
$$

PHYSICAL PROPERTIES OF GASES AND VAPORS

\begin{tabular}{lccc}
\hline \multicolumn{1}{c}{ Gas } & $\begin{array}{c}\text { Chemical } \\
\text { Formula }\end{array}$ & $\begin{array}{c}\text { Molecular } \\
\text { Weight } \mathbf{M}\end{array}$ & $\begin{array}{c}\text { Molecular } \\
\text { Diameter } \\
\left(10^{-8} \mathbf{c m}\right)\end{array}$ \\
\hline Hydrogen & $\mathrm{H}_{2}$ & 2.016 & 2.74 \\
Deuterium & $\mathrm{D}_{2}$ & 4.028 & 2.74 \\
Helium & $\mathrm{He}^{2}$ & 4.002 & 2.18 \\
Methane & $\mathrm{CH}_{4}$ & 16.04 & 4.14 \\
Ammonia & $\mathrm{NH}_{3}$ & 17.03 & 4.43 \\
\hline Water vapor & $\mathrm{H}_{2} \mathrm{O}$ & 18.02 & 4.60 \\
\hline Neon & $\mathrm{Ne}_{\text {Nitrogen }}$ & 20.18 & 2.59 \\
Oxygen & $\mathrm{N}_{2}$ & 28.01 & 3.75 \\
Argon & $\mathrm{O}_{2}$ & 31.99 & 3.61 \\
Carbon dioxide & $\mathrm{A}$ & 39.94 & 3.64 \\
Krypton & $\mathrm{CO}_{2}$ & 44.01 & 4.59 \\
Xenon & $\mathrm{Kr}$ & 83.80 & 4.11 \\
Mercury & $\mathrm{Xe}$ & 131.30 & 4.85 \\
\hline & $\mathrm{Hg}$ & 200.59 & 4.26 \\
\hline
\end{tabular}


$\operatorname{Cos} 25-10$ (Rev 6-18-92)

Stoves 26-15510,00

ENGINEERING COMPUTATION SHEET

Tile of Project Determine mass of water of

Project No.

Subject hydration on cropped MTR assembly works Computer WSL Date

$3 / 12 / 97$ Sheet No. C4

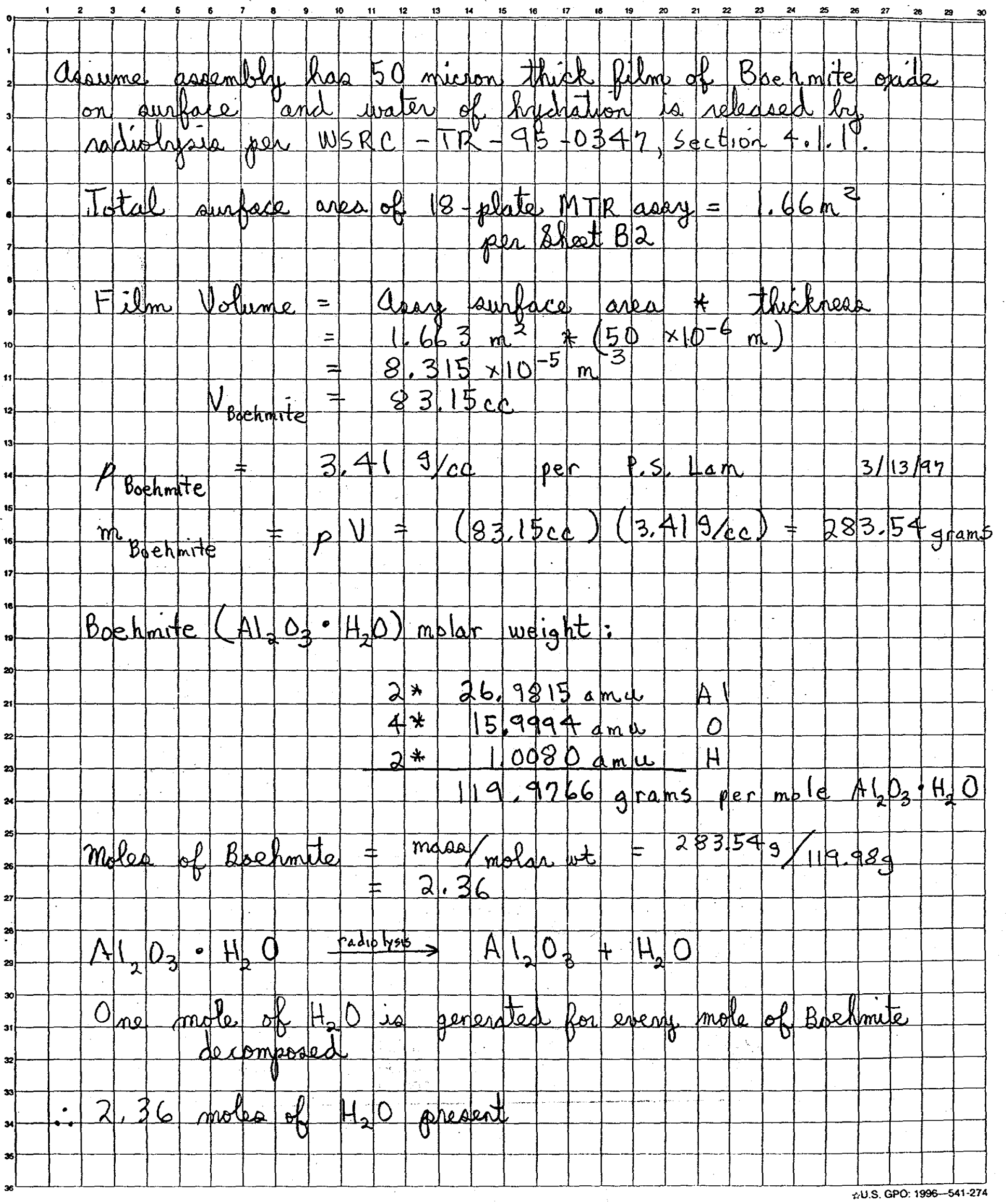


OSR 25-10 (Rev 6.18.92)
Stores: $26-15510.00$

Stores: 26-15510.00

ENGINEERING COMPUTATION SHEET

Project No.

Subject

Works

SER

Computer WW S

Date

$3 / 12 / 97$

Sheet No. $\subseteq 5$

$H_{2}$ O molar weight:

$$
\begin{array}{r}
2 * 1.0080 \text { amu } \mathrm{H} \\
\hline 15.9994 \text { amu } 0 \\
\hline 18.0154 \text { grams pe }
\end{array}
$$

18.0154 grants per mole $H_{2} \mathrm{O}$

$$
\begin{aligned}
& \text { asa } \quad=\text { number of moles * molar eight } \\
& =\quad 2.36 \text { moles } * 18.01549 / \text { mole } \\
& \begin{array}{c}
m \text { water ct } \\
\text { hydration }
\end{array}=42.58 \text { grams }
\end{aligned}
$$


OshA 2i-1i. (Rev 6-1R-92)

ENGINEERING COMPUTATION SHEET

WSRC-TR $-97-0075$

Title of Project Determine maximum hydrogen Subject. pressure inside SNF canister

Project No.

Appendix D Works

Computer W. W. Large Date $3 / 19 / 97$
SIS

Sheet No. D1

Total amount of water on cropped M TR assembly includes:

- Free water

- water of hydration

- adsorbed water
16.60019

$42.576 \mathrm{~g}$ from sheet $C 1$

fum she ct 05

from sheet $C_{2}$

Assume all 5.1 .191 grams of $H_{2} 0$ ia eased and corrodes aluminum to form new boehmite for the following equation.

$$
2 \mathrm{Al}+4 \mathrm{H}_{2} \mathrm{O}=\mathrm{Al}_{2} \mathrm{O}_{3} \cdot \mathrm{H}_{2} \mathrm{O}+3 \mathrm{H}_{2}
$$

W SR $-T R-95=0347$

p. 24

Cocumina the reaction goes to completion 3 moles of $H_{2}$ gas will be produced for every 4 moles of $\mathrm{H}_{2} \mathrm{O}$ consumed.

$\mathrm{H}_{2} \mathrm{O}$ molar weight $=18.0154 \mathrm{~g} / \mathrm{mole}$ from sheet c 5

$$
\begin{aligned}
& \text { Mole of } \mathrm{H}_{2} \mathrm{O}=59.191 \mathrm{~g} / 18.0154 \mathrm{~g} / \mathrm{mole}=3.2816 \\
& \text { moles of } \mathrm{H}_{2} \text { puoducd }=3 / 4 * 3.286=2.464
\end{aligned}
$$

The volume of 1 mole of amy gas at standard Temperature and Pressure $\left(14.696 \mathrm{psia}\right.$ and $\left.0^{\circ} \mathrm{C}\right)$ is 22.4 liters.

General College chemistry p.180

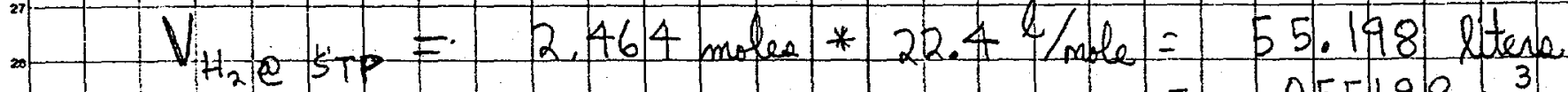
$=.055198 \mathrm{~m}^{3}$ 
$\cos 25-10$ (Rev 6-18-92)

ENGINEERING COMPUTATION SHEET

Title of Project

Subject
Project No.

Works

Date

$3 / 19 / 99$

Shes No. 02

Computer

WSL

$7 \times 2 \times 2 \times 2 \times$

Determine volume of proposed SRS SNF du y ate rag canjater:

$$
\begin{aligned}
& I D=17^{\prime \prime} \quad \text { Length }=10 \mathrm{ft}=1201 \\
& V_{\text {Canister }}=\pi / 4 D^{2} L=\pi / 4(17 \mathrm{~h})^{2}(120 \mathrm{in})=27237 \mathrm{in}^{3} \\
& V_{\text {canister }}=0.4464 \mathrm{~m}^{3}
\end{aligned}
$$

Determine volume of one copped RINC MTR anomaly:

18 fuel plates with exposed dimensions of 25.00 " thy 2.557 " by 0.060 ' per Sheet B1

2 atumentim vide plate o with dimensions of $25.5^{\prime \prime} \mathrm{by}$ 3.045 " by $0.188^{\prime \prime}$ per sheet B.1

MTR Volume:

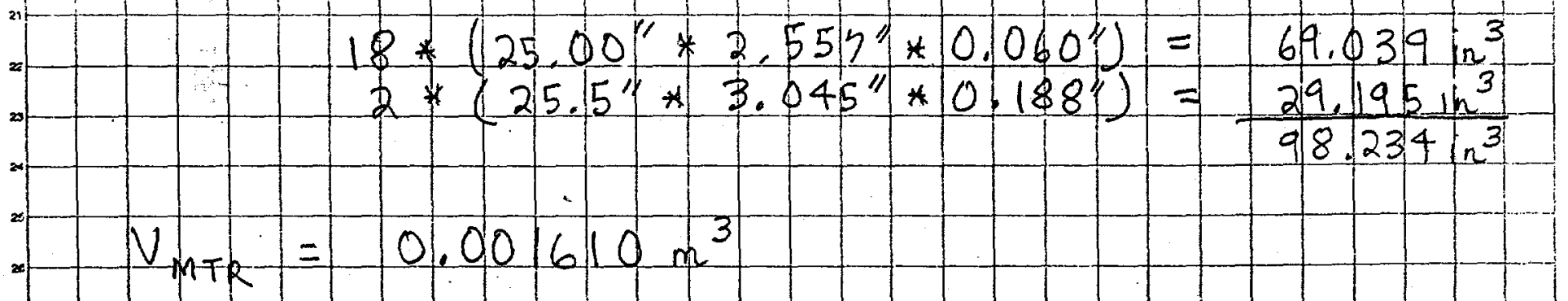

* Assume canister contains 18 M TR aremblie:

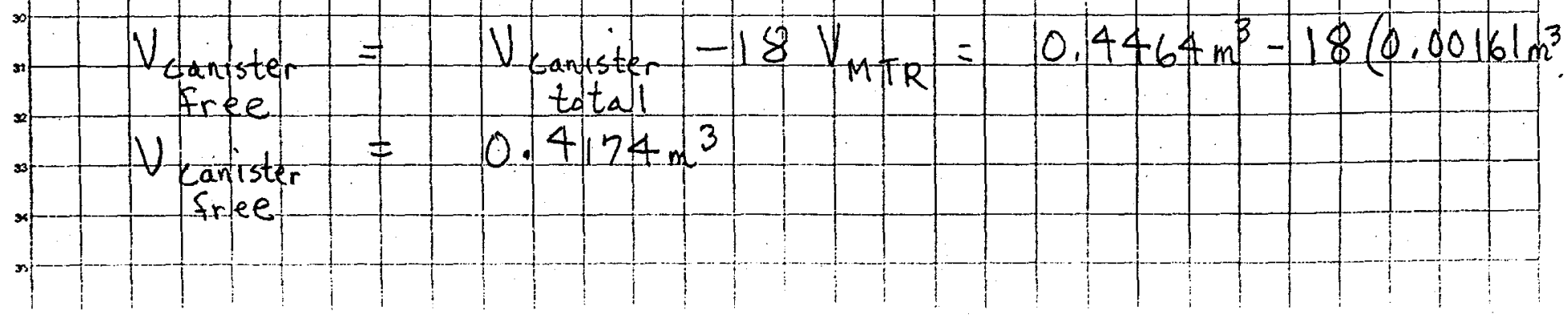


OSR 25-10 (Rev 6-18-92)

Stores: 20.1551000

ENGINEERING COMPUTATION SHEET

Project No.

SRS

Subject

Works

$W S L$

Date

$3 / 19 / 97$

Sheet No. D3

Detenmine maximum $\mathrm{H}_{2}$ presoure inside $17^{\prime \prime}$ by $10 \mathrm{ft}$ comiester. contanineng 18 MTR ascemblie at $20^{\circ} \mathrm{C}$ :

$$
\begin{aligned}
& V_{\text {Ha SSP }}=0.055198 \mathrm{~m}^{3} \text { per anar } \\
& V_{H R S S T P}=18\left(0.055198 \mathrm{~m}^{3}\right)=0.99356 \mathrm{~m}^{3} \\
& V_{\text {canister }}=0.41 \mathrm{n}^{2} \mathrm{~m}^{3} \\
& \text { free }
\end{aligned}
$$

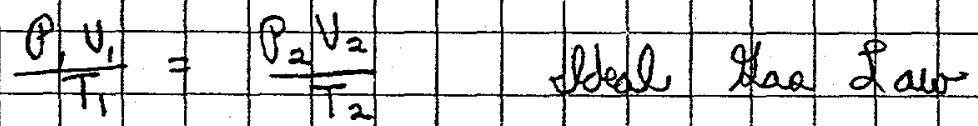

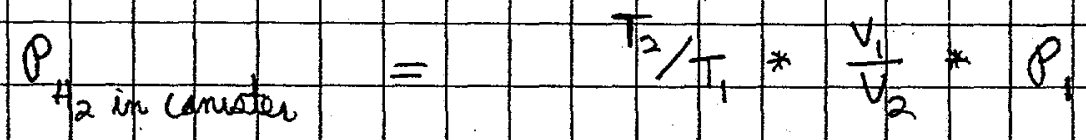

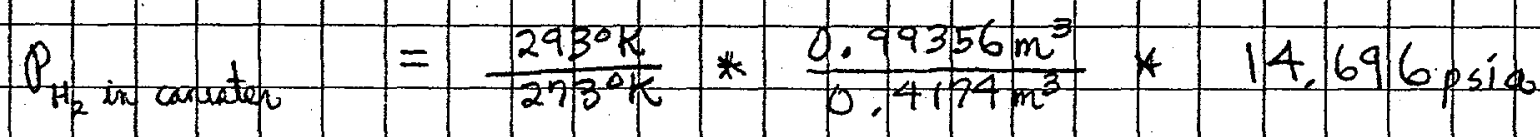

$$
\begin{aligned}
& P_{H_{2}}=37.544 \text { siat }=22.8 p \text { sig }
\end{aligned}
$$

ceternative check:

$$
\begin{aligned}
& m_{\mathrm{H}_{2} \mathrm{O}} \text { on } 18 \text { adeemblies }=18(\$ 9.1919 / \mathrm{ass} \mathrm{y})=1065.4 \mathrm{~g} \\
& V_{\text {TW }}=m \rho_{\mathrm{H}_{2} \mathrm{O}}=1065.4 \mathrm{~g} / 0.098703 \% \mathrm{gcc}=1067.36 \mathrm{cc}(\mathrm{ml}) \\
& F W N=292505 \frac{P_{H_{2}}}{(243.15+T)} \quad \text { wskc-TR-95-0342 p.24 } \\
& 1067.36 \mathrm{nV} / 0.4174 \mathrm{~m}^{3}=262505 \frac{P_{\mathrm{H}_{2}}}{(273.5+20)} \\
& P_{H_{2}}=2.56 \mathrm{dtm}=37.66 \text { psia } \approx 22.9 \mathrm{psip}
\end{aligned}
$$




\section{WESTINGHOUSE SAVANNAH RIVER CO. REPORT WSRC-TR-97-0075 \\ DISTRIBUTION}

\section{SAVANNAH RIVER SITE}

T. L. Capeletti, 773-41A

N. C. Iyer, 773-A

M. R. Louthan, Jr., 773-A

J. P. Howell, 773-41A

H. B. Peacock, Jr., 773-A

P. S. Lam, 773-41A

W. F. Ayres, 773-41A

J. D. Hurd, 705-K

W. C. Bugher, 707-C

W. N. Jackson, 707-C

J. R. Murphy, 707-C

W. F. Swift, 707-C

O. J. Williams, 717-K

B. K. Coker, 707-C

J. C. Guy, 707-C

M. W. Barlow, 704-C

R. J. Skwarek, 704-C

J. M. Carter, 707-C

B. D. Clark, 707-C

W. S. Large, 707-C

D. R. Shelton, 707-C

R. L. Sindelar, 773-41A

MTS File, 773-A

Records Storage, 773-52A 